Article

\title{
An Evaluation of Risk-Based Agricultural Land-Use Adjustments under a Flood Management Strategy in a Floodplain
}

\author{
Muhammad Atiq Ur Rehman Tariq ${ }^{1,2, * \mathbb{D}}$, Zohreh Rajabi ${ }^{1}$ and Nitin Muttil ${ }^{1,2, * \mathbb{D}}$ \\ 1 College of Engineering and Science, Victoria University, Melbourne 8001, Australia; \\ zohreh.rajabi@live.vu.edu.au \\ 2 Institute for Sustainable Industries \& Liveable Cities, Victoria University, P.O. Box 14428, \\ Melbourne 8001, Australia \\ * Correspondence: atiq.tariq@yahoo.com (M.A.U.R.T.); Nitin.Muttil@vu.edu.au (N.M.)
}

Citation: Tariq, M.A.U.R.; Rajabi, Z.; Muttil, N. An Evaluation of Risk-Based Agricultural Land-Use Adjustments under a Flood Management Strategy in a Floodplain. Hydrology 2021, 8, 53. https:// doi.org/10.3390/hydrology 8010053

Academic Editor: Pierfranco Costabile

Received: 18 February 2021

Accepted: 19 March 2021

Published: 21 March 2021

Publisher's Note: MDPI stays neutral with regard to jurisdictional claims in published maps and institutional affiliations.

Copyright: (C) 2021 by the authors. Licensee MDPI, Basel, Switzerland. This article is an open access article distributed under the terms and conditions of the Creative Commons Attribution (CC BY) license (https:// creativecommons.org/licenses/by/ $4.0 /)$.

\begin{abstract}
Agricultural damage due to floods in the Indus basin's fertile land has been the most damaging natural disaster in Pakistan so far. Earthen dikes are protecting the vast areas of the floodplain from regular flooding. However, the floodplain is attractive to farmers due to its fertility and experiences regular crop production within and out of the dike area. This paper evaluates the flood risk in a floodplain of the Chenab river in Pakistan and recommends land-use changes to reduce the flood risk for crops and associated settlements within the study area. The objective of the land-use change is not just to reduce flood losses but also to increase the overall benefits of the floodplain in terms of its Economic Rent (ER). This preliminary study analyses the economic impacts of the risk-based land-use improvements on existing floodplain land uses. Expected Annual Damage (EAD) maps were developed using hydrodynamic models and GIS data. The developed model identified the areas where maize can be economically more productive compared to rice under flood conditions. Promising results were obtained for the settlement relocations. It was also observed that the infra-structure, running parallel to the river, plays a significant role in curtailing the extent of floods. The results show that a combination of structural and non-structural measures proves more effective. The study also recommends the inclusion of social and environmental damages as well as other types of non-structural measures to develop the most effective flood management strategy.
\end{abstract}

Keywords: hazards; flood risks; land use; flood zoning; flood management; floodplain crops; Expected Annual Damages

\section{Introduction}

Floods have long been a natural phenomenon that triggers the largest loss of human life and economic harm worldwide [1]. Several estimates show that flood risk will rise further throughout the 21st century for many river basins because of not only climatic changes but also industrial growth and changes in land use [2,3].

Floods are the most frequent and destructive natural disasters in Pakistan. Since the establishment of the country in 1947, over 8000 people have lost their lives and economic losses have reached approximately 53.79 billion USD (all amounts are converted from Pakistani Rupees (PKR) to USD at 158 PKR to a USD throughout this manuscript) [4]. The fluvial floods prove to be the most destructive in the Indus plain of Pakistan due to the flat terrain, which is densely populated and commercially productive [5,6]. Measures have been taken to address the problem over time. An estimated unadjusted expenditure of over 113 million USD has been invested in flood work (excluding rescue and relief costs) under numerous schemes since 1977 [7,8]. Tariq and Giesen [9] analysed 90-year national flood damage data and found that the economic losses at the national level have shown a decreasing trend, whilst the frequency and magnitude of floods also have reduced 
greatly in the last decade. Nevertheless, overall, no significant reductions in flooding of agricultural land have been noticed [10].

While flood management policies in Pakistan acknowledge the importance of nonstructural measures, flood management mainly relies on flood defence, dams, spurs, studs, and other river training works, and other structural measures. The early warning system for flooding was also stated in 1975 [11]. The existing setup of flood management and emergency management for the main rivers is well supported by an early warning system. Flood zoning development was initiated in 1998 but has not yet been completely developed [11]. Until now, other types of non-structural interventions have not been formally enforced at the institutional level.

To develop the flood management strategy for a floodplain, it is important to identify and quantify all types of flood impacts in a floodplain. The essence of flood impacts defines the form of the solutions for flood management. Floods may have detrimental effects as well as positive ones. The impacts of floods can be defined as all the impacts that floods have on their climate, including drowning, wetting, erosion, deposition, destruction, recovery, insurance, maintenance, etc. [12]. A wide range of positive and negative impacts of floods occur (refer to Figure 1). For example, major floods in eastern Spain are very important for recharging groundwater aquifers used for agriculture and tourism, and for preserving coastal wetlands [13,14]. Categorization of damage determines which forms of damage in a given situation are important. It is, therefore, important to consider the types of damages to identify the appropriate steps to be taken for the melioration of flood management [15-19].

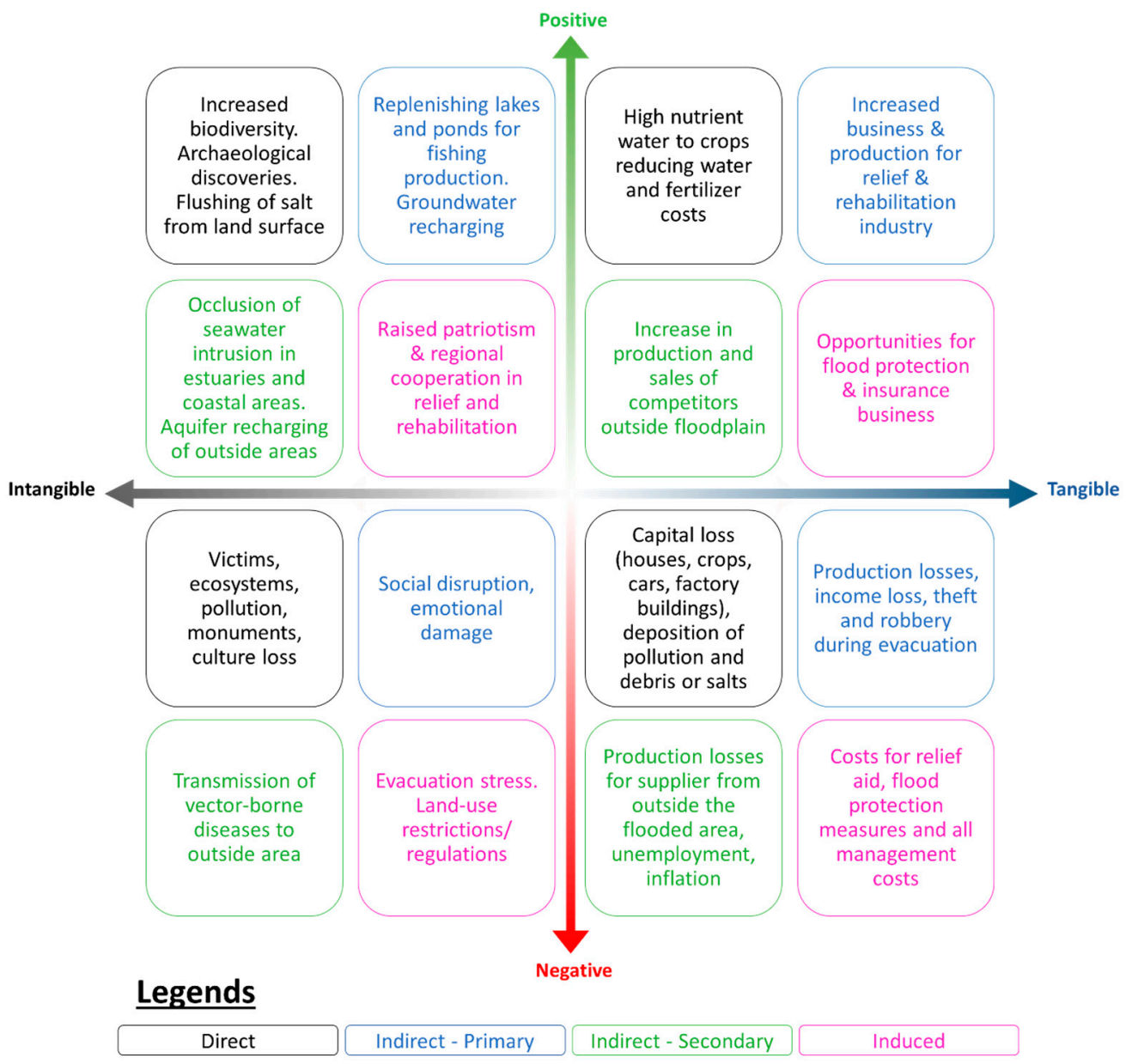

Figure 1. The classification of flood impacts in terms of Direct, Indirect-Primary, Indirect-Secondary, and Induced damages (this figure was developed based on the literature [20-25]). 
Generally, the people who settle in floodplains are the vulnerable and economically suffering group of a society [26]. They are attracted to settle in floodplains due to land resource availability at lower costs [27-29]. Unfortunately, when they are flooded frequently, it is often possible that people living in floodplains could become poorer [30-32]. On the other hand, it is very disadvantageous to abdicate the floodplain to mitigate flood damages [32,33]. The benefits of flood management related to agricultural, ecological, environmental, groundwater recharge, and business practices can be viewed as beneficial consequences of flooding. Floodplain land-use benefits can be cultured with adequate assessment of flood risk and followed up by floodplain vulnerability modifications.

As discussed in the above sections, floodplains always attract the people due to their land-use benefits. Economic activities in floodplains generate some benefits that are adversely affected by floods. It can be concluded that the flood damages in a floodplain could be either due to not utilizing the floodplain land resources or due to flooding. The objective of the proposed floodplain zoning is to "demonstrate the land-use adaptations gains in a floodplain in terms of overall agricultural land-use profit, instead of just flood loss reduction".

\section{Flood Zoning Practices}

A flood risk map displays the hypothetical flood features graphically to depict the corresponding risk [9]. These provide the information vital for land planners, flood managers, and policymakers. Unfortunately, no uniform methodology exists for the development and implementation of flood risk maps [34,35]. The intensities, extents, and other features of flood zoning maps are influenced by the geographical and hydrological characteristics of a floodplain, while the associated flood zoning regulations are inferred from the country's economic and social constraints [36]. Strict regulations on high safety standards are often tempted to take advantage of the land use. These regulations can be violated at various levels, especially in developing countries, by individuals, communities, and even by states. The associated zoning regulations, therefore, must be matched to the risk involved to ensure successful and smooth implementation of flood zoning restrictions. Therefore, the objective of flood zoning should be to ensure a maximum possible output from the floodplain by adjusting the land uses.

Many countries are introducing non-structural measures along with existing conventional structural measures. China has successfully demonstrated the growing implementation of non-structural measures into flood management strategies [37]. Land-use adaptations are significantly influenced by the structural measures as structural measures modify the hazard behaviour [38]. In the presence of existing structural measures and flood management infrastructure, the development of flood risk maps can reduce flood damages and can effectively enhance the land use in a floodplain. Therefore, the addition of a non-structural measure to support existing structural measures has the potential to increase the benefits of flood management [39].

\subsection{Floodplain Vulnerability}

Flood zoning or land-use management in a floodplain is the process to reduce flood risk by managing floodplain vulnerability [40], whereas, in contrast, structural measures manage the hazard. Floodplain vulnerability management can help to create a direct connection between the theoretical concepts of flood risk and the everyday administrative process [41]. Vulnerability management has been considered as the key factor for disaster management. It seems important to manage the floodplain vulnerability to reduce the flood risk [42]. There exist many vulnerability assessments approaches with varying vulnerability definitions, theoretical contexts, variables, and approaches to fit particular situations [43,44].

- The vulnerability indicators method uses the available data to have a logical location of vulnerability.

- The vulnerability curve method outlines the association between flood risk and risk components to help to analyse through analytical loss or fragility curves. 
- The disaster loss data method is created on data collection from real events, hazards.

- Modelling methods use computer models to evaluate the depth, elevation, and velocity of a flood using the frequency, magnitude, and shape of the hydrograph.

\subsection{Flood Management Scheme Design System}

The flood management strategy in any floodplain consists of two distinctive classes [45]:

- $\quad$ floodplain support system;

- floodplain management system.

The support system is an information system necessary to initiate flood management actions, whereas the management system consists of structural and non-structural as well as long-term and emergency measures. To develop a comprehensive floodplain management plan, one needs a detailed flood hazard mapping combined with different information systems, including the weather system, rainfall-runoff characteristics, flood wave propagation, improved inundation modelling, physical-based modelling, in situ engineering measures, and the socio-economic setup in a floodplain. This information helps in developing storm forecasting, flood forecasting, and emergency warning systems [46-50]. Figure 2 explains both components of the flood management scheme decision system.

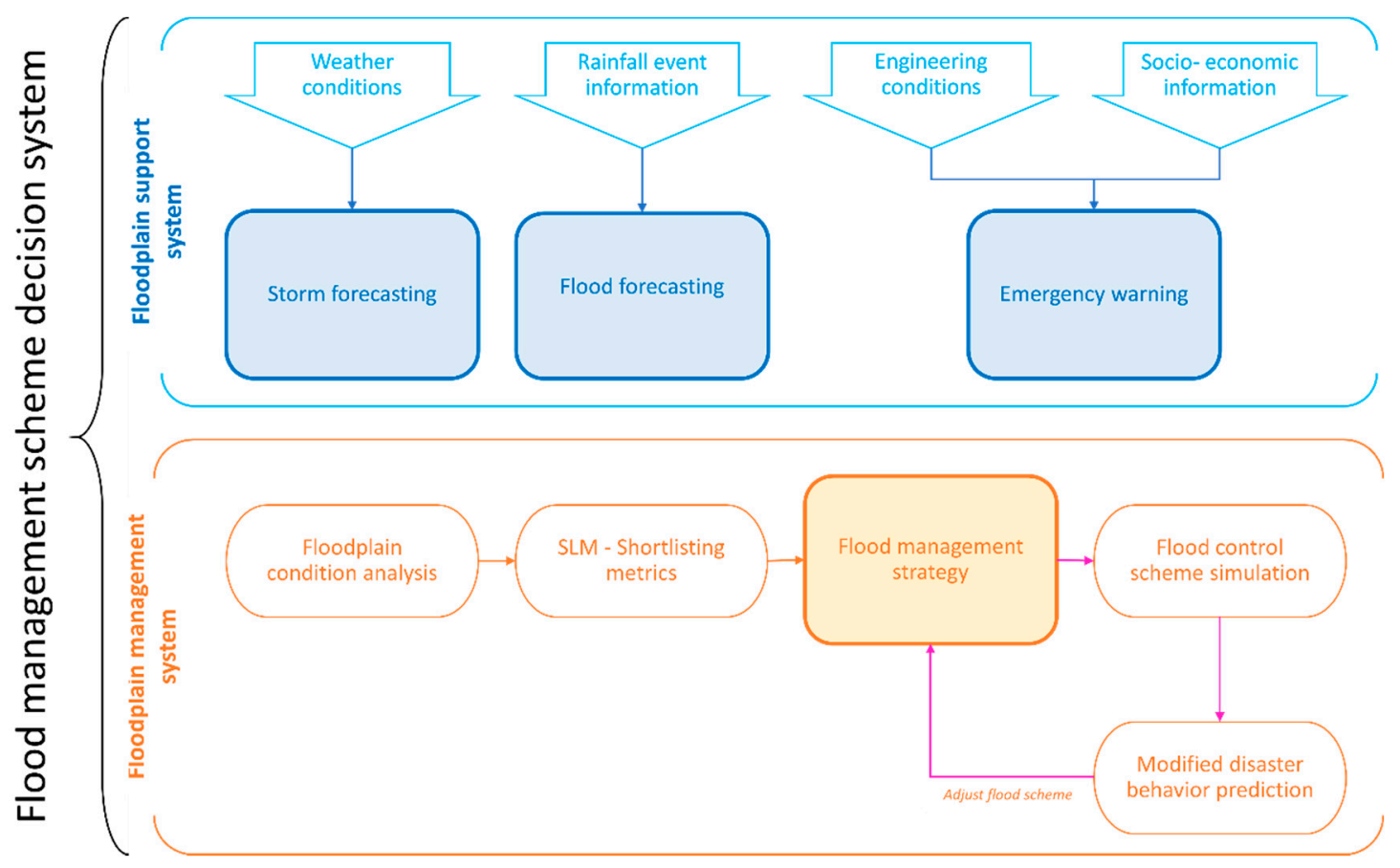

Figure 2. Flood management scheme design system consisting of the management and support components.

Once the floodplain supporting system is established, the development of an effective floodplain management system can be established on a substantial knowledgebase. An initial floodplain analysis is required to shortlist the measures that can be proven effective under the floodplain conditions. Figure 3 provides a short-listing matrix (SLM) for the short-listing of flood management measures.

Once the initial flood management arrangements are shortlisted, the modified flooding behaviour needs to be simulated/modelled to evaluate the effectiveness of the modifications under the expected flooding scenarios. Based on the induced behavioural changes, necessary improvement in the flood management strategy can be developed and re-evaluated to reach a best practice in a floodplain. 


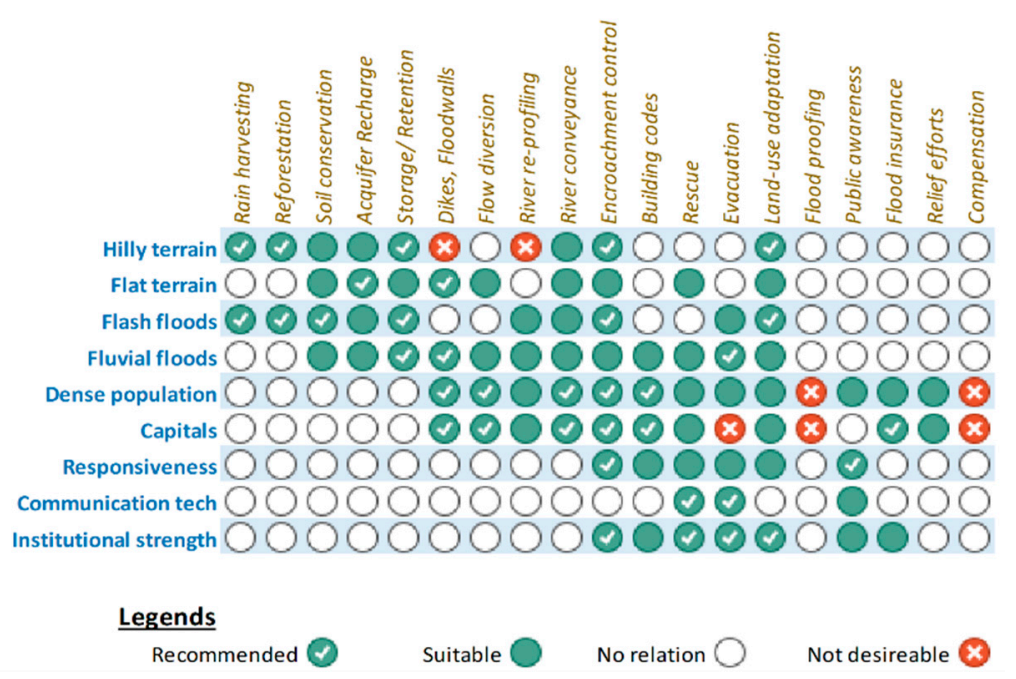

Figure 3. A typical example of a short-listing matrix (SLM) for flood management options (source: [51]).

\subsection{Flood Mapping Practices}

Various flood management methods are used to prevent or reduce the detrimental effects of floodwaters. Many models or methods are being used around the world to assess, explore, and identify intervention measures to mitigate the effects of the flood [52-60]. HECRAS, Sobek, Mike12, XP-SWMM, TUFLOW, and OpenFlows FLOOD are widely used for hydrodynamic modelling of floods generally [61]. Satellite imagery is used commonly with many software tools, including mapping, hydrodynamic modelling, hydrometeorological modelling, and risk assessments [62-72]. Different studies have used ASTER, MODIS, Proba-V, Landsat, Sentinel-2, Synthetic Aperture Radar (SAR) data collected by Sentinel1, ERS-2/SAR, ENVISAT / ASAR, RADARSAT-I, Light Detection And Ranging (LiDAR) elevation data, TerraSAR-X, SPOT, and SRTM DEM for flood mapping. Rainfall-related satellite images, like Tropical Rainfall Measuring Mission (TRMM) and Global Ensemble Forecast System (GEFS), are also used for flood mapping purposes.

There exist many general standards, frameworks, and legislations in different countries for flood risk management [73]. Germany has the federal states that implement the flood risk management legislations. In the UK, flood risk management is implemented and handled at the central government level [74,75]. Federal Flood Commission of Pakistan (FFC) is the federal agency that develops the flood management plans and strategies at the national level with the help of the provincial irrigation and drainage authorities in Pakistan [9].

\subsection{Study Area}

The Chenab River is the main source of fluvial floods in Pakistan. It runs like an unregulated river, with no suitable location for large storage reservoirs in Pakistan. The Baghlayar and Salal hydropower dams in India (run-of-the-river projects) have no bearing on flood peak attenuation due to their limited storage capacity and mismatched operating practices of reservoirs. Even more frequent and severer flooding is expected in the future due to continuous erosion in upstream hill catchment areas. The Chenab River is $1240 \mathrm{~km}$ long and has a catchment of $67,500 \mathrm{~km}^{2}$, excluding the main tributaries like Jhelum, Ravi, and Sutlej. It eventually drains into the Indus River [34]. A 42-km-long reach has been chosen between Khanki Headworks and Qadarabad Barrage for this research (refer to Figure 4). In the absence of an appropriate flood storage option and effective flood warning system for this initial reach of the river in Pakistan, the implementation of risk-based flood zoning can be highly helpful for this floodplain. 


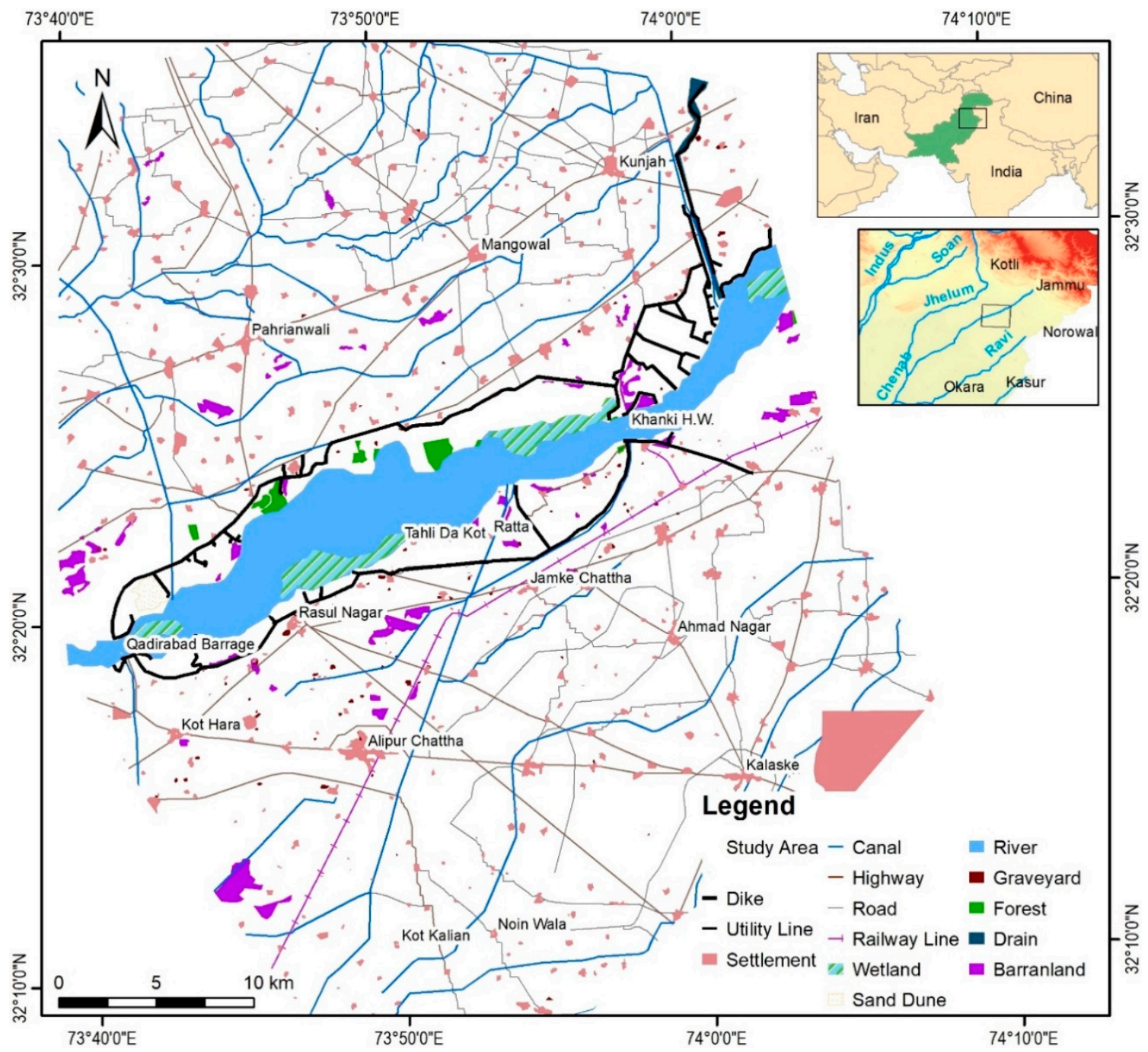

Figure 4. A 42-km-long floodplain reach study area starting upstream of the Khanki Headworks to Qadarabad Barrage.

\section{Risk-Based Approach}

A risk-based approach has been used to develop a flood map in the study area. The conceptual approach to determine the hazard, vulnerability, and risk assessment is represented in Figure 5 [51,76-78]. Risk components and parameters have been defined according to Figure 5 to identify their role in our study. The risk involved for the current land-use has been calculated based on defined parameters. Preliminary flood zoning has been calculated for the settlements and agricultural activities. As mentioned in Figure 5, the targeted area is the floodplain, and the targeted factor is "Land use" for the agricultural area.

Risk can be described as an "estimate of possible hazard-related outcomes", while risk dynamics can be characterized as the interaction of a hazard with vulnerability [79]:

Risk $=$ Hazard $\times$ Vulnerability .

Hazard is defined by probability and severity, whereas exposure and sensitivity are the functions of weakness.

Hazard $=$ Probability $\times$ Intensity;

Vulnerability $=$ Susceptibility $\times$ Exposure. 


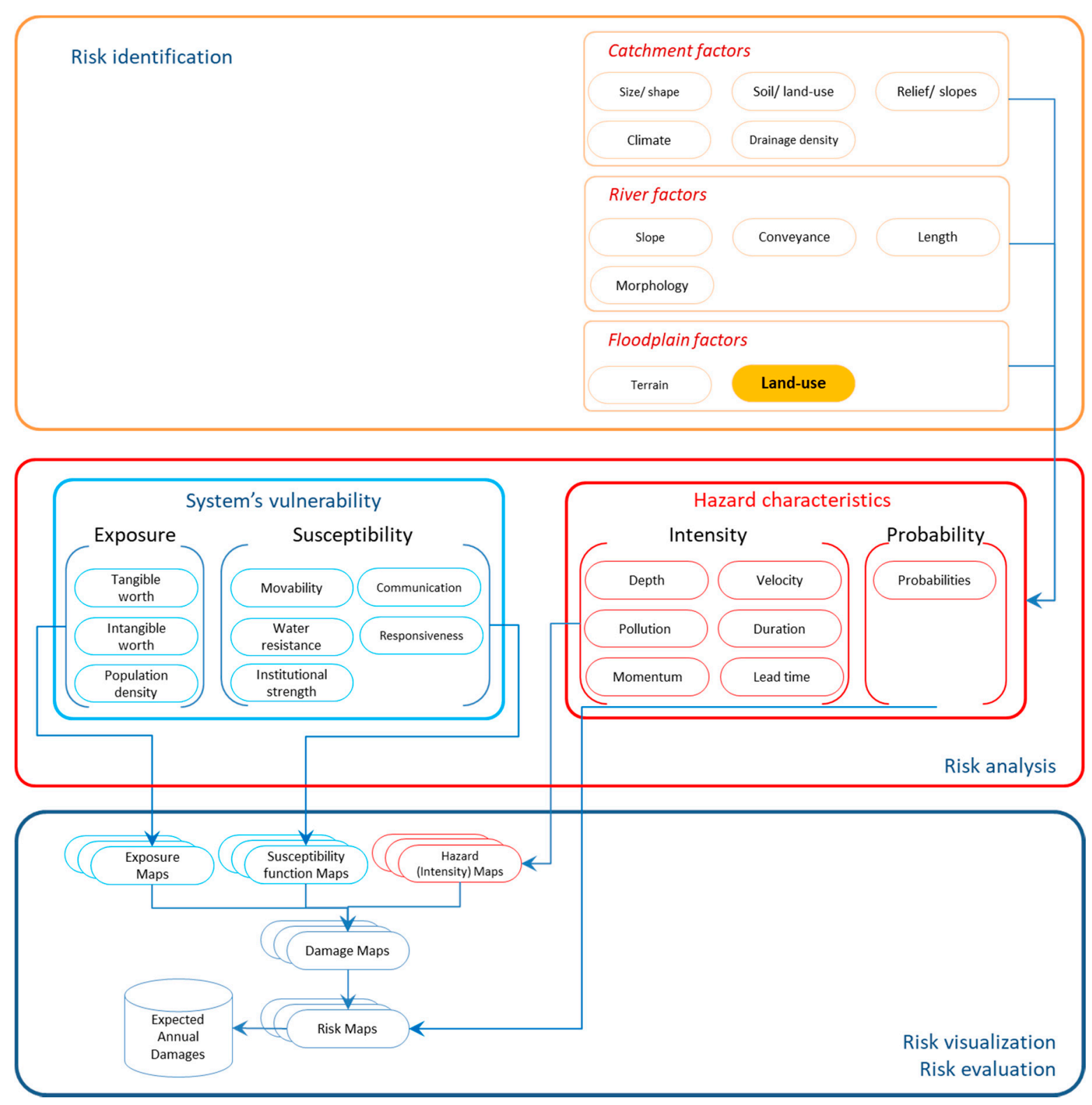

Figure 5. A guiding flowchart expressing the conceptual approach to determine the hazard, vulnerability, and risk assessment.

\subsection{Hazard Assessment}

Probability means the probability of a hazard happening in a time frame. The probability of a flood, denoted by the inverse of the return period, can be defined based on their frequency or probability [80]. Ranging from a 2-year to 10,000-year return period, ten different flood scenarios were modelled in this study.

Intensity is that property of a hazard that causes the damage. Either one or more independent parameters of a hazard can be used to exhibit the intensity of a hazard [81,82]. As the terrain in our case is flat, low speeds and longer flood lengths are expected. The adequate criterion representing the flood intensity can be the floodwater levels.

\subsection{Vulnerability Assessment}

A flood of the same intensity may produce different losses in different areas due to the difference in exposure as well as resistance and preparedness of the societies. Flood response (susceptibility) is the property that depends on the ability of assets or people living in a floodplain to withstand the negative consequences of floods. The flood response 
of a society is often characterized using intensity-damage curves [83]. For this purpose, we used the stage-damage correlations developed for areas similar to our study areas. The stage-damage functions are accepted as the standard approach to assessing direct flood damage [84-86] and the same is used in our research. Accurate information on historical flood losses is very rarely available; therefore, estimates are often accompanied by large margins [87]. In our case, appropriate damage functions have been developed by consulting the literature, various sources, and previous projects on the best-suited basis. Our dominant sources were local authorities, Chen (1999), Wang and Xiang, and the ANFAS project (Data Fusion for Flood Analysis and Decision Support) (refer to Figure 6). Equation (1) shows the stage-damage function " $F_{a}(d)$ " used in our case studies. If " $D_{a}$, max" is the maximum possible damage for a particular land-use " $\mathrm{a}$ ", then damage " $\mathrm{D}_{\mathrm{a}, \mathrm{i}}$ " against a flood of probability " $\mathrm{i}$ " can be found using the following equation.

$$
D_{a, i}=F_{a}(d) \times D_{a, \max }
$$

Exposure is the values/life that is present in the floodplain [88]. Land-use maps were developed to express the exposure in the study area.

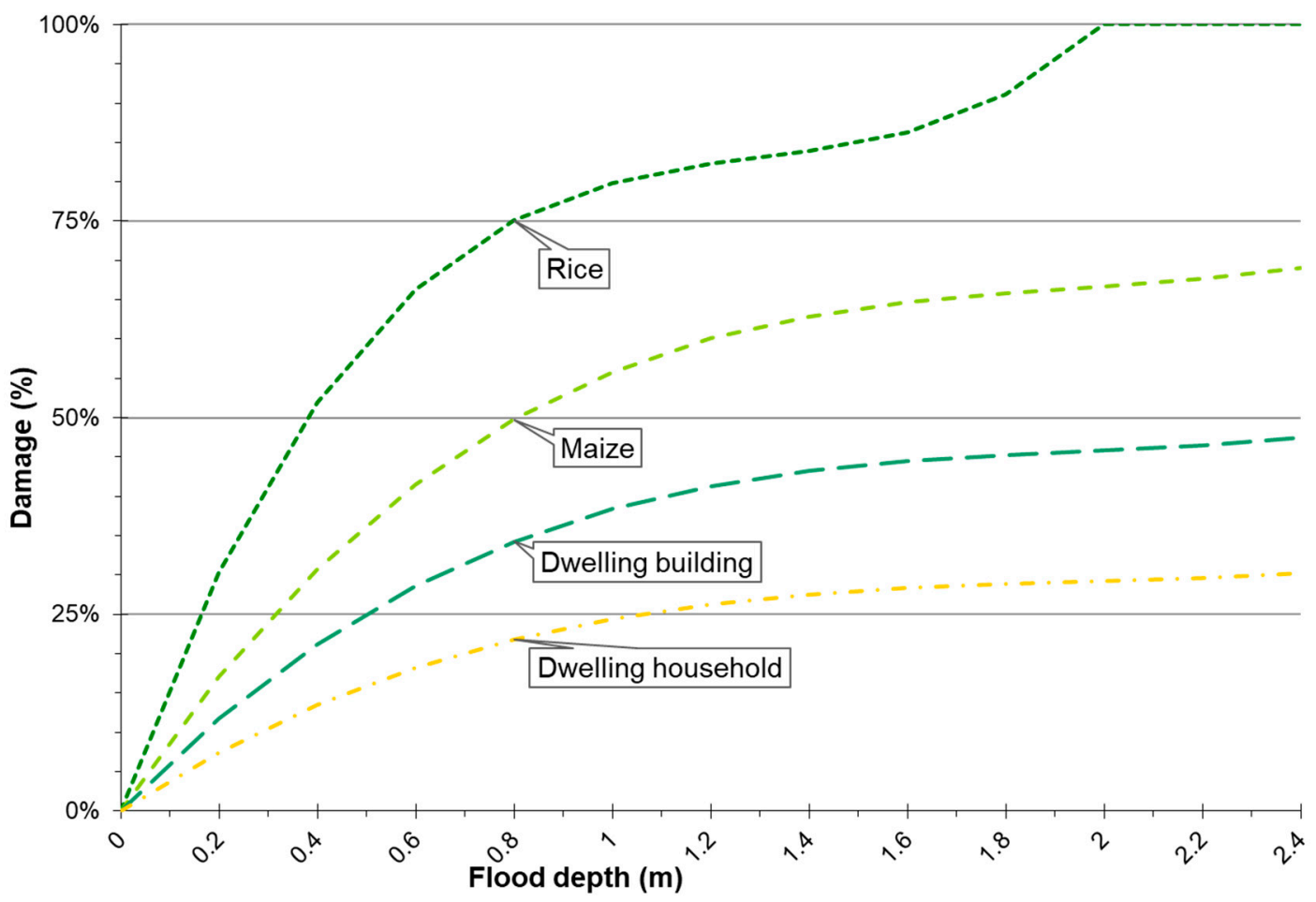

Figure 6. Stage-damage functions adapted from local authorities, Chen (1999), Wang and Xiang, and the ANFAS project [89-91].

\subsection{Economic Rent (ER)}

An increase in land-use efficiency due to reduced flooding is a benefit, which is obtained due to flood management. Economic rent (ER) considers the efficiency of land uses in a floodplain. ER is defined as the net annual revenue associated with a resource that can be obtained from a land use in a floodplain $[92,93]$. ER is an indicator that combines the effectiveness of alternatives to achieve the economic objectives of floodplain management.

It is also possible to define the net annual return per unit of land as the difference of the annual gross returns to total costs (excluding land rent), which represents economic efficiency [93]. In case of a floodplain, the annual cost of the measure includes capital and maintenance costs, and the expected residual damage reduce the ER; these are called combined deductions. 
"Location benefits" $\left(\mathrm{R}_{\mathrm{loc}}\right)$ and "intensifying benefits" $\left(\mathrm{R}_{\mathrm{int}}\right)$ are the two components of ER (please refer to Equation (2)). $R_{\text {loc }}$ is connected with the availability of land for intensive economic uses, e.g., shifting from agriculture to industrial land use [94], whereas $R_{\text {int }}$ is the value of increasing land use, such as changing from lower- to higher-value crop cultivation or, alternatively, producing higher-yield crops or intensifying agricultural economic activities [94].

$$
\Delta R_{n}=\Delta R_{\text {loc }}+\Delta R_{\text {int }}
$$

\subsection{Risk Assessment}

The first of its type, a hydro-economic model, was developed by the US Army Corps of Engineers (USACE) to estimate EAD in the 1990s [95]. This model establishes relationships between flood discharge, stage, frequency, and damage. Based on the static nature and inability to cope with the changing conditions of the rivers, catchments, and floodplains of USACE's hydro-economic model, Tariq et al. recommend using a GIS-based hydrodynamic model to account for any variation in river flow and floodplain $[17,81,96]$. The EAD is calculated by multiplying the average flood damages to their incremental probabilities, as shown in Equation (3).

$$
\mathrm{EAD}=\sum_{i=0}^{i=\infty} \mathrm{D}_{\mathrm{i}} \times \Delta \mathrm{P}_{\mathrm{i}}
$$

whereas

$$
D_{i}=\frac{D_{P_{i-1}}+D_{P_{i}}}{2}
$$

\subsection{Assumptions}

The studies performed are based on a few assumptions that can fairly represent the floodplain conditions in a simplified and more reliable way. The collected annual flood data shows that the floods occur from July to September when the maize and rice are cultivated in the floodplain. The same is assumed for all crop land-use purposes. In the same way, only direct damages are considered to keep the estimates reliable and precise.

Relocation of settlements involves multiple administrative as well technical issues. The proposed relocation is performed purely on a theoretical basis and provides an idea of flood losses in case these settlements were located at two different locations. The settlements' direct displacements from their existing locations were calculated for the additional traveling distances, irrespective of the road networks.

\section{Methodology}

The methodology for our research is extracted from Figure 5, which represents a general risk-based conceptual approach. The customized stepwise methodology used for the development of agricultural land-use practices (cropping and settlements) in a floodplain is presented in Figure 7. The first phase consists of developing the GIS models and hydrodynamic models required to perform the simulations. In the second phase, zoning for cropping and settlements are performed. 


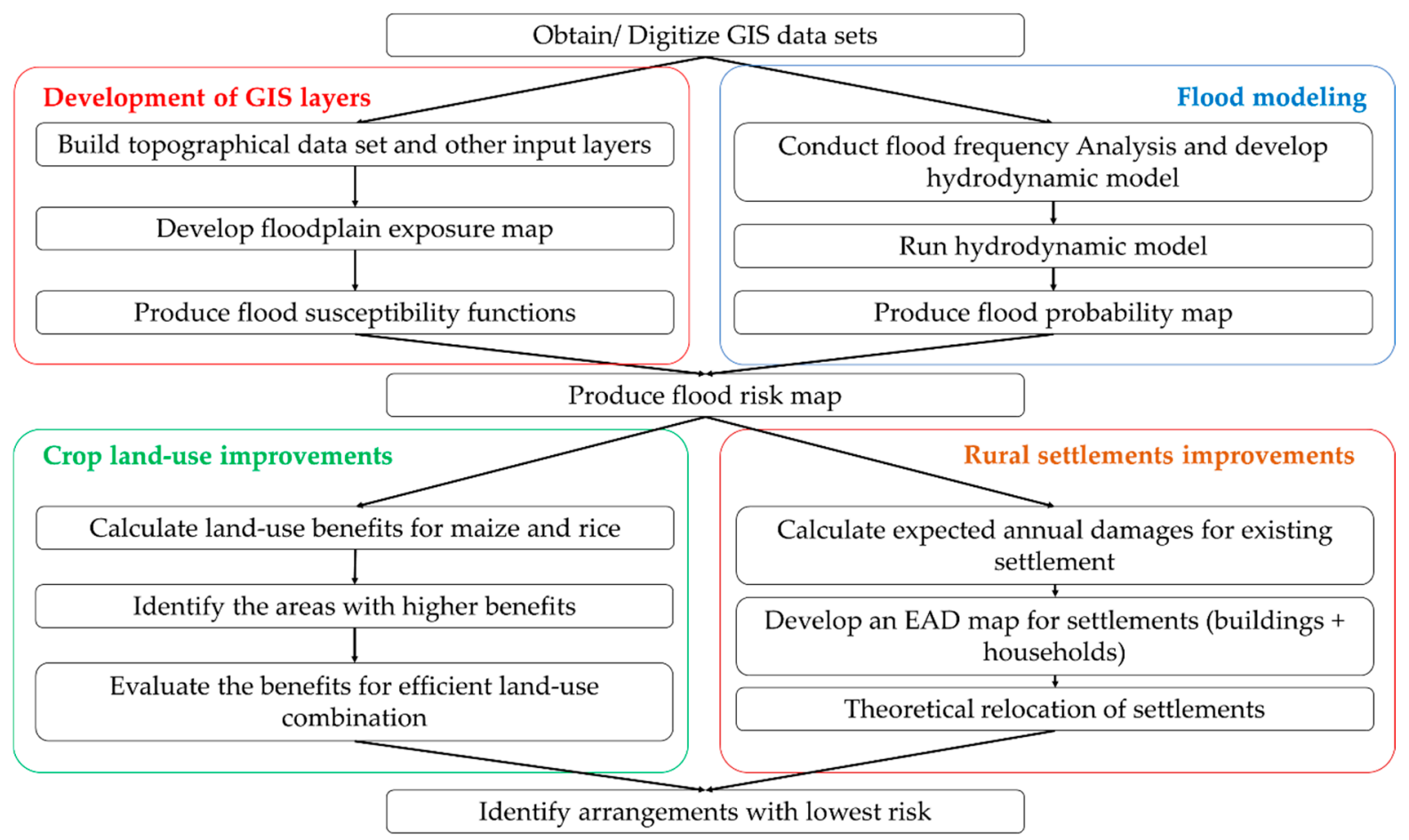

Figure 7. An elaborated step-by-step procedure for the agriculture and settlements land-use method derived from Figure 5.

\subsection{Development of GIS Layers}

Land-use maps for the study area reach were developed from the topographic sheets obtained from the Survey of Pakistan, Google maps, and ground-truthing. The map is used to represent the exposure in a floodplain. Approximately ten land-use divisions and six utility forms (GIS-format polylines) were digitized for this study.

\subsection{Flood Modelling}

To conceptualize the probabilistic nature of floods, a detailed frequency analysis was performed to cover all possible flood scenarios. Frequency analyses were carried out using 80 years of historic annual peak flow data. "Design Flood" software was used to perform frequency analysis [97]. The most suitable frequency distribution that fits the data was Log Pearson type III, estimated using the moment method. Floods with 2, 5, 10, 25, 50, $100,500,1000,5000$, and 10,000 years return periods were analysed to assess the overall flooding behaviour in the study area floodplain. It was decided to consider these 10 floods to represent the probable flooding scenario to ensure that the flood management is not based on a fixed probable flood.

Hydrodynamic simulation of inundation depths and floodplain extents were performed in the Sobek 1D-2D Rural module using a 90-m-resolution Digital Elevation Model (DEM). The DEM was derived primarily from elevation data of the Shuttle Radar Topography Mission (SRTM) obtained from the HydroSHED [98,99]. Considering the extent of the large study area, computing capabilities, availability of data and resources, and the reliability of results thus obtained, confirmed the suitability of DEM as acceptable if not the ideal. Initial flood extents were developed using HECRAS 1D to get an idea of the expected coverage area for extreme floods. The model was run to simulate all expected floods for their depths and extents. A potential scenario with flood depths of all expected floods weighted by their probabilities is shown in Figure 8. 


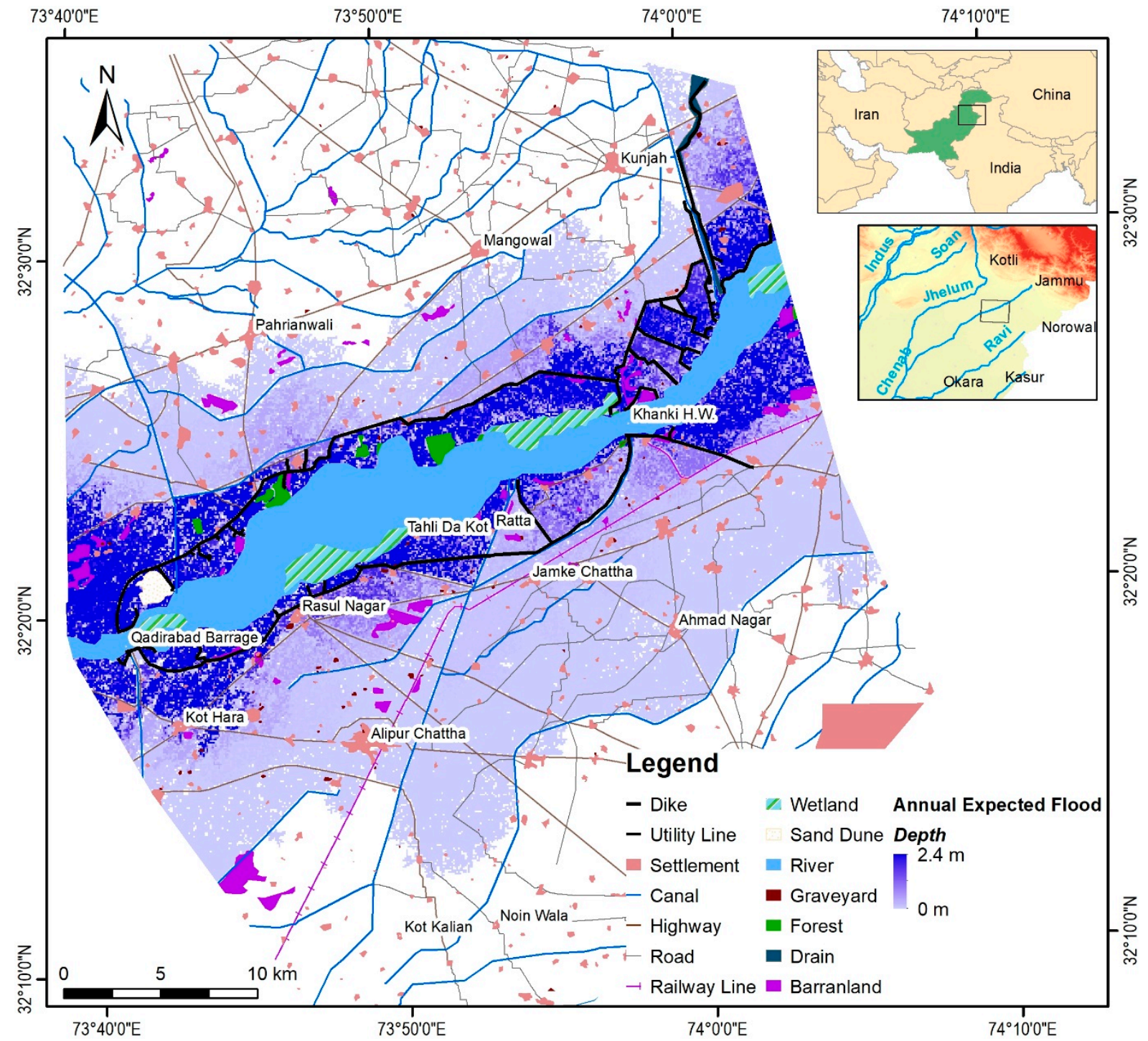

Figure 8. Expected flooding scenario showing weighted overlaid flood spreads and depths of different probabilities in the study area, from Khanki Headworks to Qadarabad Barrage, Chenab River, Pakistan.

\subsection{Cropping Practices}

As the risk depends upon hazard and vulnerability. Modifications in land use can change the flood risk due to altered vulnerability in a floodplain. The most efficient landuses can be identified for all floodplain areas. Due to the significant contribution in total flood damage of the study area, settlements and cropping land were chosen for preliminary zoning in our research [97].

Using the stage-damage functions shown in Figure 6 and the typical costs and profits of the farmers, the stage-damage functions were converted into stage-profit/loss curves. Figure 9 describes the left-over profit for rice crop and maize crop against different inundated depths. Rice crop is more profitable in the absence of flooding but much impairing otherwise due to loss of high capital investments. On the other hand, maize is less profitgaining in normal conditions but bears fewer losses under flooding situations. For the maize crop, there is less capital involved. In addition, maize has a shorter growing period and can be harvested even earlier to use as animal fodder in case of flooding predictions. Normally, a part of the field is harvested until the cropping field is flooded.

Foresting can be considered an alternative to crops in an agricultural area. However, foresting is not considered a replacement because it will not allow cultivating a second season crop $[5,6]$. Foresting will also increase flow resistance to flood waters, thus spreading 
flood to a wider area. The procedure includes the calculation of the expected profit of maize and rice crops under the expected floods. The best land-use practice is the one where the more profitable crop is cultivated. The flood damage functions make maize more profitable in flooded areas (refer to Figure 9).

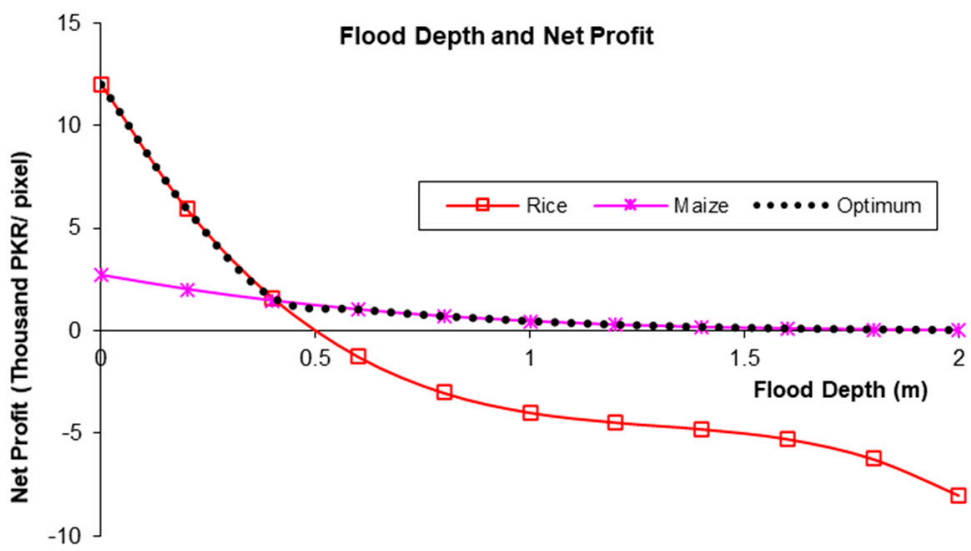

Figure 9. Reduction in profits due to flooding for maize and rice crops.

\subsection{Settlement Zoning}

The second important land use in a rural area for zoning purposes is settlements. If all settlements are developed outside of the floodplain then flood losses can be brought to zero theoretically, but a majority of these settlements consist of people who have their economic activities related to a river or the land in the surroundings of the river. The inhabitants need to visit the area regularly for their livelihood. If these settlements are developed outside the floodplain then their traveling expenditures, duration, and efforts become exceptionally high and might be unaffordable. This is the reason why these people choose to live within the floodplain even after being aware of the flood risk. In an extreme situation, if the settlements are in close vicinity to the river then there would be devastating losses due to frequent floods and if these are much further away, then the losses/costs due to traveling might become too high. The location of the settlements can be optimized by minimizing the combined losses of floods and traveling (refer Figure 10). A suitability analysis of the settlement locations was performed regarding their existing locations.

For calculation purposes, building damages and household damages were calculated separately to avoid oversimplification. Settlement suitability does not cover the merging of settlements due to cultural, social, and administrative reasons. It was made assured that the cultural unity and persuasion of people living within the same area should not be disturbed.

It is assumed that about half of the population has a business that is primarily connected to the river and its surrounding area, whereas the rest of the people are involved in providing community services and their proximity to the river does not matter if they are relocated. Based on the data collected from the "Household Integrated Economic Survey (HIES) 2018-19" [100], the average number of persons in a household, area of a house, and the number of earning persons of a household have been determined as 5.84 members per household in Punjab rural. On average, two persons from a household are connected to earning jobs. The cost of displacement of one settlement pixel per kilometre was calculated considering the annual average petrol price and conventional tractor as the traveling method. The final loss for a settlement can be defined as the sum of the flood loss plus its distance cost. Relocation of settlements was proposed to the nearest location to minimize travel losses. 

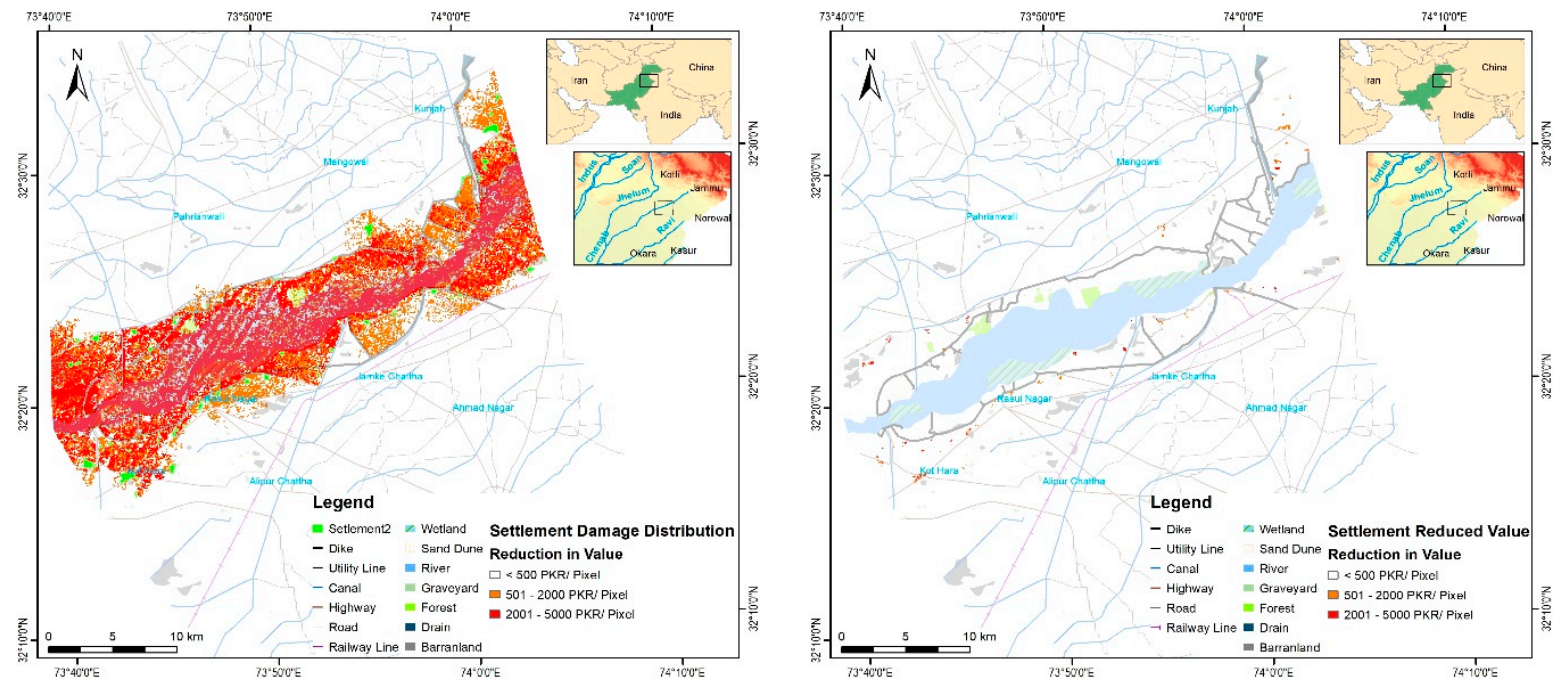

Figure 10. Combined risk map for buildings and households, showed on the left, while the right map shows the damage to the existing settlements.

\section{Results and Discussions}

Figure 11 shows the profit distributions for both crops (top left and top right), areas where maize is preferable (bottom left), and the optimum cropping distribution in the study area (bottom right). Replacement of rice with maize is recommended on an area of $106.55 \mathrm{~km}^{2}$. Rice in this area is causing a 0.200 million USD loss to the farmers, whereas the maize in the same area can generate a profit of 0.144 million USD. This replacement can generate an additional gain of 0.342 million USD, which is equivalent to $3228 \mathrm{USD} / \mathrm{km}^{2}$ on average.

There are 68 settlements with a total area of 482.64 ha being affected in the study area floodplain. At present, the expected flood damage to these settlements are 0.508 million USD annually, which can be reduced to 0.011 million USD annually by the relocation of settlements. However, the traveling cost is increased significantly, 0.174 million USD annually, thus resulting in a net reduction of 0.323 million USD annually.

In case the cropping and settlements are adapted to the proposed adjustments, a total of 0.664 million USD annually can be saved in the study area.

A further investigation and analysis revealed some further facts. Figures 10-12 show that the recommended agricultural zone, as well as the high-risk settlement area, lie in the area that is inundated under a 5-year return period flood. In the area where a flood comes every second year, land use is already adapted to flood situations. Ground truthing confirms that no settlements or high-value crops are cultivated within that area. On the other hand, exceedingly rare floods have no significant risk due to their low probability and therefore land-use change mitigation might not be economically feasible. The area that is flooded by a 5-year flood and not by a 2-year flood suffers the most. A 2-year return period flood remains fresh in people's memories; that is why the land use in this area already complies with the flood considerations. A 5-year period is a relatively long interval and the farmers who remain careful suffer during no flooding episodes. This is the area where flood zoning is required and can be useful. With a lesser probability of flood, it becomes more difficult to persuade the floodplain inhabitants to follow the flood zoning restrictions.

It is also observed that the flood extents are curtailed by the dikes, roads, and railway lines. The area of flood inundations could be much wider in the absence of these structures. The overall flood reduction can be optimized by optimizing the combined effect of all measures. 

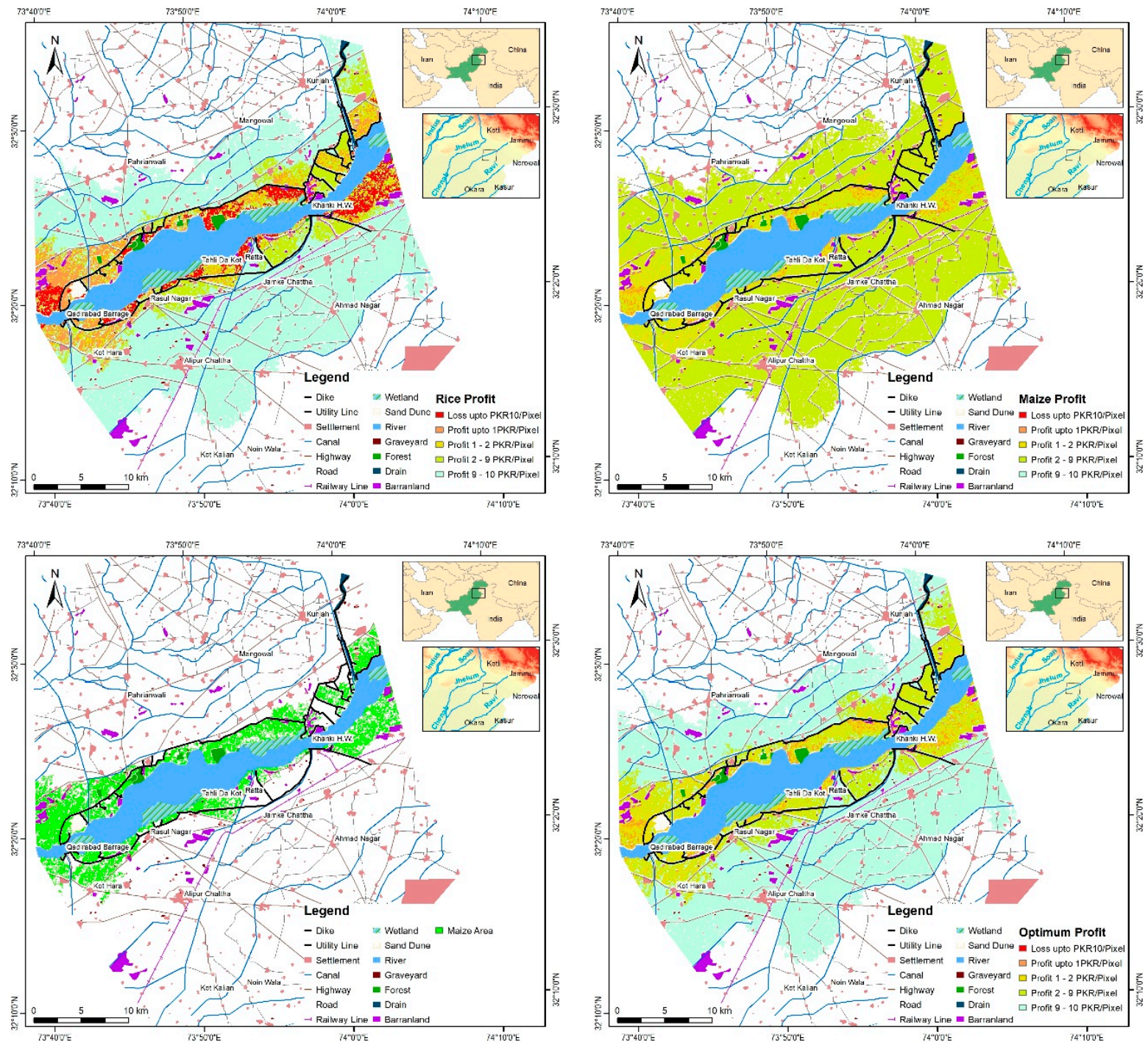

Figure 11. Top left map shows the spatial distribution of profit for rice crops in the floodplain. The top right map shows the profit for maize. The bottom left map shows the area where maize is more profitable compared to rice in the floodplain. The bottom right shows the ideal combination of maize and rice in the floodplain. 


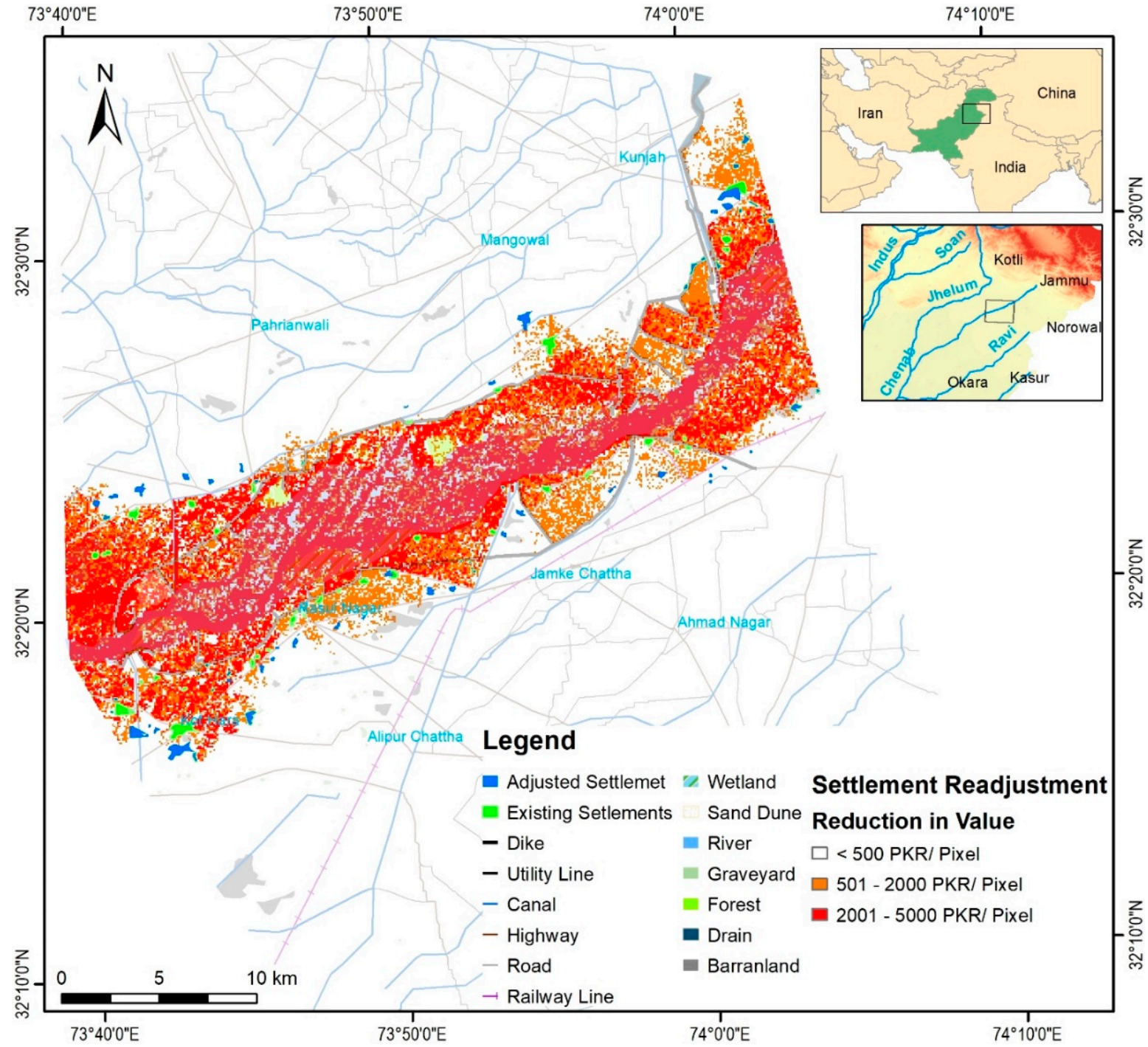

Figure 12. The map showing the adjustments of settlements with minimum departures from their original locations.

\section{Conclusions and Recommendations}

Based on the results, a fluvial floodplain, such as the one in our study area, can be divided into three zones:

1. Frequent flooding zone.

2. Medium flooding zone.

3. Rare flooding zone.

A frequent flooding zone is the one where the inhabitants are well versed in flooding and have already adapted the lifestyle to flooding with minimum exposure in the floodplain. This is generally the 2-year return period flood zone. A rare flooding zone is the one where a flood occurs rarely (greater than a 50-year return period), and restraining floodplain land use may prove counterproductive. The most critical area is where the flood zoning might prove to be effective-in and between the 2-year return period flood to 50-year return period floodplain. The measures should be flexible and supported with incentives and appropriate guidance.

The results also support a combination of non-structural measures with structural measures. An adequate combination will not only reduce the flood losses but also enable to take the maximum advantage of land-use in terms of economic rent. Therefore, it is obvious that the use of structural measures extensively affects non-structural measures. It is also noticed that the roads, railway lines, and other infrastructures running parallel to the 
river also play some role to reduce the flood extent. It could be a good option if the design phase of infrastructure in the floodplain also considers the flood management aspects. A flood management strategy must be well designed by considering the potential land uses, economic activities, and cultural setups. The choice and combination of options will depend on the nature of the flood problem and the objectives of the management strategy. Combining different flood management options may provide more efficient, economical, and viable management. There cannot be a single generalized solution for all floodplains but there can be a single acceptable approach for consistent standards throughout the country.

A risk-based approach would lead to an economic, social, and environmental balance between gains and losses. Introducing zoning can be advantageous because of reducing losses and increasing the land-use benefits. These results should be used as an important input to the decision-making process for water managers and politicians.

Economic losses are not the only types of losses, and zoning is not the only option; all potential flood management strategies and all forms of economic, social, and environmental advantages and drawbacks should be regarded to be more productive and for systematic optimization.

Author Contributions: Conceptualization, M.A.U.R.T.; formal analysis, M.A.U.R.T.; investigation, M.A.U.R.T. and N.M.; methodology, M.A.U.R.T. and Z.R.; project administration, M.A.U.R.T. and N.M.; software, M.A.U.R.T. and Z.R.; supervision, M.A.U.R.T. and N.M.; visualization, M.A.U.R.T. and Z.R.; writing—original draft, M.A.U.R.T. and Z.R.; writing—review and editing, M.A.U.R.T. All authors have read and agreed to the published version of the manuscript.

Funding: This research received no external funding.

Conflicts of Interest: The authors declare no conflict of interest.

\section{References}

1. Doocy, S.; Daniels, A.; Murray, S.; Kirsch, T.D. The Human Impact of Floods: A Historical Review of Events 1980-2009 and Systematic Literature Review. Plos Curr. 2013. [CrossRef] [PubMed]

2. O'Donnell, E.C.; Thorne, C.R. Drivers of future urban flood risk. Philos. Trans. R. Soc. A: Math. Phys. Eng. Sci. 2020, 378. [CrossRef]

3. Hallegatte, S.; Green, C.; Nicholls, R.J.; Corfee-Morlot, J. Future flood losses in major coastal cities. Nat. Clim. Chang. 2013, 3. [CrossRef]

4. Ahmad, D.; Afzal, M. Flood hazards and factors influencing household flood perception and mitigation strategies in Pakistan. Environ. Sci. Pollut. Res. 2020, 27, 15375-15387. [CrossRef]

5. US Census International Database. Blue Marble Citizen, Pakistan Population. 2018. Available online: https://www. bluemarblecitizen.com/world-population/Pakistan (accessed on 28 February 2021).

6. OCHA. Pakistan: Population Density (as of 26 August 2013)—Pakistan I ReliefWeb. 2013. Available online: https://reliefweb. $\mathrm{int} / \mathrm{map} /$ pakistan/pakistan-population-density-26-august-2013 (accessed on 28 February 2021).

7. De Graaf, R.; Van De Giesen, N.; Van De Ven, F. Alternative water management options to reduce vulnerability for climate change in the Netherlands. Nat. Hazards 2007, 407-422. [CrossRef]

8. Shah, A.A.; Gong, Z.; Ali, M.; Jamshed, A.; Naqvi, S.A.A.; Naz, S. Measuring education sector resilience in the face of flood disasters in Pakistan: An index-based approach. Environ. Sci. Pollut. Res. 2020, 27, 44106-44122. [CrossRef] [PubMed]

9. Tariq, M.A.U.R.; Van De Giesen, N. Floods and flood management in Pakistan. Phys. Chem. Earthparts A/B/C 2012, 47-48, 11-20. [CrossRef]

10. Sassi, M.; Nicotina, L.; Pall, P.; Stone, D.; Hilberts, A.; Wehner, M.; Jewson, S. Impact of climate change on European winter and summer flood losses. Adv. Water Resour. 2019, 129, 165-177. [CrossRef]

11. De Moel, H.; Van Alphen, J.; Aerts, J.C.J.H. Flood maps in Europe-methods, availability and use. Nat. Hazards Earth Syst. Sci. 2009, 9, 289-301. [CrossRef]

12. Tsang, M.; Scott, D.M. An integrated approach to modeling the impact of floods on emergency services: A case study of Calgary, Alberta. J. Transp. Geogr. 2020, 86, 102774. [CrossRef]

13. EEA Annual Report 2003-European Environmen. Available online: https://www.eea.europa.eu/publications/corporate_ document_2004_2 (accessed on 2 October 2020).

14. Giannaros, C.; Kotroni, V.; Lagouvardos, K.; Oikonomou, C.; Haralambous, H.; Papagiannaki, K. Hydrometeorological and Socio-Economic Impact Assessment of Stream Flooding in Southeast Mediterranean: The Case of Rafina Catchment (Attica, Greece). Water 2020, 12, 2426. [CrossRef] 
15. Merz, B.; Kreibich, H.; Thieken, A.; Schmidtke, R. Estimation uncertainty of direct monetary flood damage to buildings. Nat. Hazards Earth Syst. Sci. 2004, 4, 153-163. [CrossRef]

16. Dutta, D.; Herath, S.; Musiake, K. Direct flood damage modeling towards urban flood risk management. Joint Work- shop on Urban Safety Engineering. 2001, pp. 123-135. Available online: https://www.researchgate.net/profile/Srikantha_Herath/ publication/237805907_Direct_flood_damage_modeling_towards_urban_flood_risk_management/links/53d5c6b60cf228d363 ea10e5/Direct-flood-damage-modeling-towards-urban-flood-risk-management.pdf (accessed on 2 October 2020).

17. Tariq, M.; Hoes, O.; Van De Giesen, N. Development of a risk-based framework to integrate flood insurance. J. Flood Risk Manag. 2013, 7, 291-307. [CrossRef]

18. De Bruijn, K.M.; van Beek, E. Resilience and Flood Risk Management: A Systems Approach Applied to Lowland Rivers. Ph.D. Thesis, Technische Universiteit Delft, Delft, The Netherlands, 2005.

19. angtze River Flood Control and Management Project Literature Review for a Socio-Economic Impacts Assessment Procedure for Qianliang Hu Detention Basin, Yangtze River Flood Control and Management Project. 2003. Available online: https://d1rkab7tlqy5f1.cloudfront.net/TBM/Over\%20faculteit/Afdelingen/Values\%2C\%20Technology\%20and\%20 Innovation/People/Full\%20Professors/Pieter\%20van\%20Gelder/Citations/citatie119.pdf (accessed on 8 October 2020).

20. McGrath, H.; El Ezz, A.A.; Nastev, M. Probabilistic depth-damage curves for assessment of flood-induced building losses. Nat. Hazards 2019, 97, s11069-s019. [CrossRef]

21. Carrera, L.; Standardi, G.; Bosello, F.; Mysiak, J. Assessing direct and indirect economic impacts of a flood event through the integration of spatial and computable general equilibrium modelling. Environ. Model. Softw. 2015, 63, 109-122. [CrossRef]

22. Gao, Z.; Geddes, R.R.; Ma, T. Direct and Indirect Economic Losses Using Typhoon-Flood Disaster Analysis: An Application to Guangdong Province, China. Sustain. J. Rec. 2020, 12, 8980. [CrossRef]

23. Koks, E.E.; Bočkarjova, M.; De Moel, H.; Aerts, J.C.J.H. Integrated Direct and Indirect Flood Risk Modeling: Development and Sensitivity Analysis. Risk Anal. 2014, 35, 882-900. [CrossRef]

24. Tanoue, M.; Taguchi, R.; Nakata, S.; Watanabe, S.; Fujimori, S.; Hirabayashi, Y. Estimation of Direct and Indirect Economic Losses Caused by a Flood with Long-Lasting Inundation: Application to the 2011 Thailand Flood. Water Resource. Res. 2020, 56. [CrossRef]

25. Thieken, A.H.; Piroth, K.; Schwarz, J.; Schwarze, R. Methods for the evaluation of direct and indirect flood losses. In Proceedings of the 4th International Symposium on Flood Defence (ISDF), Toronto, ON, Canada, 5-8 May 2008.

26. Arlikatti, S.; Maghelal, P.; Agnimitra, N.; Chatterjee, V. Should I stay or should I go? Mitigation strategies for flash flooding in India. Int. J. Disaster Risk Reduct. 2018, 27, 48-56. [CrossRef]

27. Dilley, M.; Chen, R.S.; Deichmann, U.; Lerner-Lam, A.L.; Arnold, M. Natural Disaster Hotspots; The World Bank: Washington, DC, USA, 2005.

28. Shi, P.; Yang, X.; Xu, W.; Wang, J. Mapping Global Mortality and Affected Population Risks for Multiple Natural Hazards. Int. J. Disaster Risk Sci. 2016, 7, 54-62. [CrossRef]

29. Porse, E. Risk-based zoning for urbanizing floodplains. Water Sci. Technol. 2014, 70, 1755-1763. [CrossRef] [PubMed]

30. Mushar, S.H.M.; Ahmad, S.S.S.; Kasmin, F.; Kasmuri, E. Flood Damage Assessment: A Preliminary Studies. Environ. Res. Eng. Manag. 2019, 75, 55-70. [CrossRef]

31. Domańska, D.; Wojtylak, M. Application of fuzzy time series models for forecasting pollution concentrations. Expert Syst. Appl. 2012, 39, 7673-7679. [CrossRef]

32. Bowes, B.D.; Tavakoli, A.; Wang, C.; Heydarian, A.; Behl, M.; Beling, P.A.; Goodall, J.L. Flood mitigation in coastal urban catchments using real-time stormwater infrastructure control and reinforcement learning. J. Hydroinform. 2020. [CrossRef]

33. Sanders, B.F.; Grant, S.B. Re-envisioning stormwater infrastructure for ultrahazardous flooding. Wiley Interdiscip. Rev. Water 2020, 7. [CrossRef]

34. Pottier, N.; Penning-Rowsell, E.; Tunstall, S.; Hubert, G. Land use and flood protection: Contrasting approaches and outcomes in France and in England and Wales. Appl. Geogr. 2005, 25, 1-27. Available online: http://www.sciencedirect.com/science/article/ pii/S0143622804000402 (accessed on 8 October 2020). [CrossRef]

35. Completion Report PAK: Second Flood Protection Sector Project;Asian Development bank. 2007. Available online: https: / /www.adb.org/sites/default/files/project-document/65951/28165-pak-pcr.pdf (accessed on 2 October 2020).

36. Pourghasemi, H.R.; Razavi-Termeh, S.V.; Kariminejad, N.; Hong, H.; Chen, W. An assessment of metaheuristic approaches for flood assessment. J. Hydrol. 2020, 582, 124536. [CrossRef]

37. Kundzewicz, Z.; Su, B.; Wang, Y.; Xia, J.; Huang, J.; Jiang, T. Flood risk and its reduction in China. Adv. Water Resour. 2019, 130, 37-45. [CrossRef]

38. Abebe, Y.A.; Ghorbani, A.; Nikolic, I.; Vojinovic, Z.; Sanchez, A. Flood risk management in Sint Maarten-A coupled agent-based and flood modelling method. J. Environ. Manag. 2019, 248, 109317. [CrossRef]

39. Wasson, R.; Saikia, A.; Bansal, P.; Joon, C.C. Flood Mitigation, Climate Change Adaptation and Technological Lock-In in Assam. Ecol. Econ. Soc. Insee J. 2020, 3, 83-104. [CrossRef]

40. Poussin, J.; Bubeck, P.; Aerts, J.C.J.H.; Ward, P.J. Potential of semi-structural and non-structural adaptation strategies to reduce future flood risk: Case study for the Meuse. Nat. Hazards Earth Syst. Sci. 2012, 12, 3455-3471. [CrossRef]

41. Nasiri, H.; Yusof, M.J.M.; Ali, T.A.M. An overview to flood vulnerability assessment methods. Sustain. Water Resour. Manag. 2016, 2, 331-336. [CrossRef] 
42. Gain, A.K.; Giupponi, C.; Renaud, F.G. Climate Change Adaptation and Vulnerability Assessment of Water Resources Systems in Developing Countries: A Generalized Framework and a Feasibility Study in Bangladesh. Water 2012, 4, 345-366. [CrossRef]

43. Huang, D.; Zhang, R.; Huo, Z.; Mao, F.; E, Y.; Zheng, W. An assessment of multidimensional flood vulnerability at the provincial scale in China based on the DEA method. Nat. Hazards 2012, 64, 1575-1586. [CrossRef]

44. Füssel, H.-M. Development and Climate Change Review and Quantitative Analysis of Indices of Climate Change Exposure, Adaptive Capacity, Sensitivity, and Impacts; World Bank: Washington, DC, USA, 2009.

45. Guo, S.; Zhang, H.; Chen, H.; Peng, D.; Liu, P.; Pang, B. A reservoir flood forecasting and control system for China / Un système chinois de prévision et de contrôle de crue en barrage. Hydrol. Sci. J. 2004, 49, 959-972. [CrossRef]

46. Purvis, M.J.; Bates, P.D.; Hayes, C.M. A probabilistic methodology to estimate future coastal flood risk due to sea level rise. Coast. Eng. 2008, 55, 1062-1073. [CrossRef]

47. Gouldby, B.; Méndez, F.; Guanche, Y.; Rueda, A.; Mínguez, R. A methodology for deriving extreme nearshore sea conditions for structural design and flood risk analysis. Coast. Eng. 2014, 88, 15-26. [CrossRef]

48. Anees, M.T.; Bakar, A.F.B.A.; Lim, H.S.; Abdullah, K.; Nordin, M.N.M.; Norulaini, N.; Ishak, M.I.S.; Kadir, M.O.A. Flood vulnerability, risk, and susceptibility assessment: Flood risk management. In Decision Support Methods for Assessing Flood Risk and Vulnerability; IGI Global: Hershey, PA, USA, 2019; pp. 1-27.

49. Vousdoukas, M.I.; Voukouvalas, E.; Mentaschi, L.; Dottori, F.; Giardino, A.; Bouziotas, D.; Bianchi, A.; Salamon, P.; Feyen, L. Developments in large-scale coastal flood hazard mapping. Nat. Hazards Earth Syst. Sci. 2016, 16, 1841-1853. [CrossRef]

50. Dottori, F.; Martina, M.; Figueiredo, R. A methodology for flood susceptibility and vulnerability analysis in complex flood scenarios. J. Flood Risk Manag. 2018, 11, S632-S645. [CrossRef]

51. Tariq, M.A.U.R.; Farooq, R.; Van De Giesen, N. A Critical Review of Flood Risk Management and the Selection of Suitable Measures. Appl. Sci. 2020, 10, 8752. [CrossRef]

52. Demir, V.; Kisi, O. Flood Hazard Mapping by Using Geographic Information System and Hydraulic Model: Mert River, Samsun, Turkey. Adv. Meteorol. 2016. [CrossRef]

53. Sl, G.Y.G. Flood Hazard Assessment and Mapping of Flood Inundation Area of the Awash River Basin in Ethiopia using GIS and HEC-GeoRAS/HEC-RAS Model. J. Civ. Environ. Eng. 2015, 5. [CrossRef]

54. Kaoje, I.U.; Ishiaku, I. Urban flood vulnerability mapping of lagos, nigeria. Matter Int. J. Sci. Technol. 2017, 3, 224-236. [CrossRef]

55. Lugeri, N.; Kundzewicz, Z.W.; Genovese, E.; Hochrainer, S.; Radziejewski, M. River flood risk and adaptation in Europeassessment of the present status. Mitig. Adapt. Strat. Glob. Chang. 2010, 15, 621-639. [CrossRef]

56. Biswas, S.; Mahajan, P.; Sharma, A.; Singh Baghel, D.; Nmims, I. Methodologies for Flood Hazard Mapping-A Review; NMIMS, MPSTME, SVNIT: Surat, India, 2018.

57. Gebrehiwot, A.; Hashemi-Beni, L. A METHOD TO GENERATE FLOOD MAPS IN 3D USING DEM AND DEEP LEARNING. Isprs-Int. Arch. Photogramm. Remote Sens. Spat. Inf. Sci. 2020, XLIV-M-2-2, 25-28. [CrossRef]

58. Bove, G.; Becker, A.; Sweeney, B.; Vousdoukas, M.; Kulp, S. A method for regional estimation of climate change exposure of coastal infrastructure: Case of USVI and the influence of digital elevation models on assessments. Sci. Total. Environ. 2020, 710, 136162. [CrossRef] [PubMed]

59. Zhou, X.; Zhang, Z.; Liu, X.; Wu, D.; Ding, Y.; Li, G.; Wu, Y. Typical reactive carbonyl compounds in food products: Formation, influence on food quality, and detection methods. Compr. Rev. Food Sci. Food Saf. 2020, 19, 503-529. [CrossRef]

60. Li, C.; Cheng, X.; Li, N.; Du, X.; Yu, Q.; Kan, G. A Framework for Flood Risk Analysis and Benefit Assessment of Flood Control Measures in Urban Areas. Int. J. Environ. Res. Public Heal. 2016, 13, 787. [CrossRef] [PubMed]

61. Farooq, M.; Shafique, M.; Khattak, M.S. Flood hazard assessment and mapping of River Swat using HEC-RAS 2D model and high-resolution 12-m TanDEM-X DEM (WorldDEM). Nat. Hazards 2019, 97, 477-492. [CrossRef]

62. Joyce, K.E.; Belliss, S.E.; Samsonov, S.V.; McNeill, S.J.; Glassey, P.J. A review of the status of satellite remote sensing and image processing techniques for mapping natural hazards and disasters. Prog. Phys. Geogr. Earth Environ. 2009, 33, 183-207. [CrossRef]

63. Notti, D.; Giordan, D.; Caló, F.; Pepe, A.; Zucca, F.; Galve, J.P. Potential and Limitations of Open Satellite Data for Flood Mapping. Remote. Sens. 2018, 10, 1673. [CrossRef]

64. Skakun, S. A neural network approach to flood mapping using satellite imagery. Comput. Inform. 2010, 29, 1013-1024.

65. Coltin, B.; McMichael, S.; Smith, T.; Fong, T. Automatic boosted flood mapping from satellite data. Int. J. Remote. Sens. 2016, 37, 993-1015. [CrossRef]

66. Ovando, A.; Martinez, J.; Tomasella, J.; Rodriguez, D.; Von Randow, C. Multi-temporal flood mapping and satellite altimetry used to evaluate the flood dynamics of the Bolivian Amazon wetlands. Int. J. Appl. Earth Obs. Geoinf. 2018, 69, 27-40. [CrossRef]

67. Brown, K.M.; Hambidge, C.H.; Brownett, J.M. Progress in operational flood mapping using satellite synthetic aperture radar (SAR) and airborne light detection and ranging (LiDAR) data. Prog. Phys. Geogr. Earth Environ. 2016, 40, 196-214. [CrossRef]

68. Elkhrachy, I. Flash Flood Hazard Mapping Using Satellite Images and GIS Tools: A case study of Najran City, Kingdom of Saudi Arabia (KSA). Egypt. J. Remote. Sens. Space Sci. 2015, 18, 261-278. [CrossRef]

69. Sharma, V.K.; Mishra, N.; Shukla, A.K.; Yadav, A.; Rao, G.S.; Bhanumurthy, V. Satellite data planning for flood mapping activities based on high rainfall events generated using TRMM, GEFS and disaster news. Ann. Gis 2017, 23, 131-140. [CrossRef]

70. Peng, B.; Meng, Z.; Huang, Q.; Wang, C. Patch Similarity Convolutional Neural Network for Urban Flood Extent Mapping Using Bi-Temporal Satellite Multispectral Imagery. Remote. Sens. 2019, 11, 2492. [CrossRef] 
71. Shan, J.; Hussain, E.; Kim, K.; Biehl, L. Flood mapping with satellite images and its web service. Photogramm. Eng. Remote Sens. 2010, 76, 102-104.

72. Martinis, S.; Plank, S.; Ćwik, K. The Use of Sentinel-1 Time-Series Data to Improve Flood Monitoring in Arid Areas. Remote Sens. 2018, 10, 583. [CrossRef]

73. Hegger, D.L.T.; Driessen, P.P.J.; Dieperink, C.; Wiering, M.; Raadgever, G.T.T.; Van Rijswick, H.F.M.W. Assessing Stability and Dynamics in Flood Risk Governance. Water Resour. Manag. 2014, 28, 4127-4142. [CrossRef]

74. Evans, E.; Hall, J.; Penning-Rowsell, E.; Sayers, P.; Thorne, C.; Watkinson, A. Future flood risk management in the UK. Proc. Inst. Civ. Eng.-Water Manag. 2006, 159, 53-61. [CrossRef]

75. Fleischhauer, M.; Greiving, S.; Flex, F.; Scheibel, M.; Stickler, T.; Sereinig, N.; Koboltschnig, G.; Malvati, P.; Vitale, V.; Grifoni, P.; et al. Improving the active involvement of stakeholders and the public in flood risk management-Tools of an involvement strategy and case study results from Austria, Germany and Italy. Nat. Hazards Earth Syst. Sci. 2012, 12, 2785-2798. [CrossRef]

76. Albano, R.; Sole, A.; Sdao, F.; Giosa, L.; Cantisani, A.; Pascale, S. A Systemic Approach to Evaluate the Flood Vulnerability for an Urban Study Case in Southern Italy. J. Water Resour. Prot. 2014, 6, 351-362. [CrossRef]

77. Wu, J.; Li, Y.; Li, N.; Shi, P. Development of an Asset Value Map for Disaster Risk Assessment in China by Spatial Disaggregation Using Ancillary Remote Sensing Data. Risk Anal. 2017, 38, 17-30. [CrossRef]

78. Veleda, S.; Martínez-Graña, A.; Santos-Francés, F.; Roman, J.S.-S.; Criado, M. Analysis of the Hazard, Vulnerability, and Exposure to the Risk of Flooding (Alba de Yeltes, Salamanca, Spain). Appl. Sci. 2017, 7, 157. [CrossRef]

79. UNDHA. Internationally Agreed Glossary of Basic Terms Related to Disaster Management; United Nations Department of Humanitarian Affairs: Geneva, Switzerland, 1992.

80. ADPC, UNDP, Integrated Flood Risk Management in Asia 2005. Available online: http:// repo.floodalliance.net/jspui/44111/1380 (accessed on 10 October 2020).

81. Tariq, M.A.U.R. Risk-based flood zoning employing expected annual damages: The Chenab River case study. Stoch. Environ. Res. Risk Assess. 2013, 27, 1957-1966. [CrossRef]

82. Lehner, B.; Verdin, K.; Jarvis, A. New Global Hydrography Derived From Spaceborne Elevation Data. Eos 2008, 89, 93-94. [CrossRef]

83. Merz, B.; Merz, B.; Thieken, A.; Thieken, A.; Gocht, M.; Gocht, M. Flood risk mapping at the local scale: Concepts and challenges. In Flood Risk Management in Europe; Begum, S., Stive, M.J.F., Hall, J.W., Eds.; Springer: Berlin/Heidelberg, Germany, 2007; pp. 231-251.

84. Smith, D.I. Flood damage estimation-A review of urban stage-damage curves and loss functions. Water Sa 1994, $20,231-236$.

85. Middelmann-Fernandes, M.H. Flood damage estimation beyond stage-damage functions: An Australian example. J. Flood Risk Manag. 2010, 3, 88-96. [CrossRef]

86. Yi, C.-S.; Lee, J.-H.; Shim, M.-P. GIS-based distributed technique for assessing economic loss from flood damage: Pre-feasibility study for the Anyang Stream Basin in Korea. Nat. Hazards 2010, 55, 251-272. [CrossRef]

87. Douben, K.-J. Characteristics of river floods and flooding: A global overview, 1985-2003. Irrig. Drain. 2006, 55, 9-21. [CrossRef]

88. Kron, W.; International Water Resources Association. Flood Risk = Hazard • Values • Vulnerability. Water Int. 2005, 30, 58-68. [CrossRef]

89. Chen, Y.; Xu, S.; Gu, S.; Sha, Z.; Van Gelder, P. A New Weighted Function Moments Method to Estimate Parameters of P-III Distribution with Historical Floods; Hohai University Press: Nanjing, China, 1999.

90. Zhang, J.; Zhou, C.; Xu, K.; Watanabe, M. Flood disaster monitoring and evaluation in China. Glob. Environ. Chang. Part B: Environ. Hazards 2002, 4, 33-43. [CrossRef]

91. Federal Flood Commission. Strengthening Flood Forecasting, Management and Warning System; Federal Flood Commission: Islamabad, Pakistan, 2008.

92. Weisz, R.N.; Day, J.C. A regional planning approach to the floodplain management problem. Ann. Reg. Sci. 1975, 9, 80-92. [CrossRef]

93. Fondja Wandji, Y.D.; Bhattacharyya, S.C. Evaluation of economic rent from hydroelectric power developments: Evidence from Cameroon. J. Energy Dev. 2017, 42, 239-270. Available online: https://www.jstor.org/stable/26539429? casa_token=7SzfwFcA8 zkAAAAA\%3Atf9TcKrn2RmfZ1OJWdXu6KrE3-8gAYgweczRlm3zHchgJY-ARH6Rk73TKWuAJ7-js0kk3Q1t-7uiXTkISHy5 auSXjQvEcUamqTdZkgcuSyrm6a5Ai4M\&seq=1\#metadata_info_tab_contents (accessed on 8 October 2020).

94. USACE. Engineering and Design: Risk-Based Analysis for Flood Damage Reduction Studies; U.S. Army Corps of Engineers: Washington, DC, USA, 1996.

95. Yoe, C. Framework for Estimating National Economic Development Benefits and Other Beneficial Effects of Flood Warning and Preparedness Systems; U.S. Army Corps of Engineers: Washington, DC, USA, 1994; Available online: https://apps.dtic.mil/dtic/tr/fulltext/u2 /a281145.pdf (accessed on 12 October 2020).

96. Levy, J.K.; Hall, J. Advances in flood risk management under uncertainty. Stoch. Environ. Res. Risk Assess. 2005, 19, 375-377. [CrossRef]

97. Ahmad, I. Design Flood. PC Based Hydraulic Design Packages. p. A Flood Hydrograph PC Based Package. 1994. Available online: https://global.hauraton.com/en/hydraulic-design-software/ (accessed on 12 October 2020).

98. Kron, W. Flood Risk $=$ Hazard $\times$ Exposure $\times$ Vulnerability. J. Lake Sci. 2003, 15, 190-204. [CrossRef] 
99. Ahmad, D.; Afzal, M. Flood hazards, human displacement and food insecurity in rural riverine areas of Punjab, Pakistan: Policy implications. Environ. Sci. Pollut. Res. 2020, 28, 10125-10139. [CrossRef]

100. Government of Pakistan Ministry of Planning Development \& Special Initiatives Pakistan Bureau of Statistics Islamabad. Household Integrated Economic Survey (HIES) 2018-19 I Pakistan Bureau of Statistics. Available online: https://www.pbs.gov. pk/content/household-integrated-economic-survey-hies-2018-19 (accessed on 14 February 2021). 